\title{
PERBANDINGAN KUAT TEKAN DAN KUAT TARIK LANGSUNG POLIMER MODIFIED MORTAR BERSERAT AGAVE CANTULLA ROXB DENGAN POLIMER MODIFIED MORTAR BERSERAT KACA
}

\author{
Bagas Prabowo $^{1)}$, Edy Purwanto ${ }^{2)}$, dan Stefanus Adi Kristiawan²) \\ 1) Mahasiswa Fakultas Teknik, Prodi Teknik Sipil, Universitas Sebelas Maret \\ 2) Pengajar Fakultas Teknik, Prodi Teknik Sipil, Universitas Sebelas Maret \\ J1. Ir. Sutami 36A, Kentingan Surakarta, \\ Email : reypras8@gmail.com
}

\begin{abstract}
Concrete has some advantages and some deficiencies. The advantage of concrete is the character that concrete can resist from compressive strength and the deficiency of concrete is the character that concrete can't resist from tensile strength. One of the solution to increase the resistance of concrete from tensile strength is mix the concrete with fiber. The fiber will be used are natural fiber and fabrication fiber. The natural fiber is Agave Cantula Roxb and the fabrication fiber is fiber glass. The fiber that will be mixed to Polymer Modified Mortar is a short fiber that spread randomly. the adding of short fiber has two aspects the first is fiber length and the second is volume fraction. The fiber length is $1,0 \mathrm{~cm}, 1,5 \mathrm{~cm}, 2,0 \mathrm{~cm}, 2,5 \mathrm{~cm}, 3,0 \mathrm{~cm}$ and the volume fraction is $1 \%, 2 \%, 3 \%$ from the volume of cylinder test object. The test object will be test on 3 days and 28 days for tensile strength test, for compressive strength test the test object will be test on 3 days, 7 days and 28 days. Result of testing is natural fiber have highest tensile strength on fiber length $2,0 \mathrm{~cm}$ and the volume fraction is $3 \%$ while the fabrication fiber has highest tensile strength on fiber length $2,0 \mathrm{~cm}$ and the volume fraction is $2 \%$. The compressive strength and the tensile strength of Polymer Modified Mortar with Agave Cantula Roxb Fiber is not far different from the compressive strength and the tensile strength of Polymer Modified Mortar with Fiber Glass.
\end{abstract}

Keywords: Agave Cantula Roxb Fiber, Fiber Concrete, Fiber Glass, Fiber Length, Volume Fraction.

\begin{abstract}
ABSTRAK
Beton mempunyai beberapa kelebihan dan kelemahan. Kelebihan beton yaitu kuat terhadap tekan dan kekurangan beton adalah lemah terhadap tarik. Salah satu cara untuk meningkatkan kekuatan beton terhadap gaya tarik adalah dengan menambahkan serat. Serat yang akan digunakan pada penelitian ini ada dua yaitu serat alami dan serat fabrikasi. Serat alami berupa Agave Cantula Roxb dan serat fabrikasi berupa serat kaca. Serat yang akan dicampurkan ke dalam Polymer Modified Mortar (PMM) berupa serat pendek yang disebar secara acak. Penambahan serat ditinjau dari dua aspek yaitu berdasarkan panjang serat $1,0 \mathrm{~cm}, 1,5 \mathrm{~cm}, 2,0 \mathrm{~cm}, 2.5 \mathrm{~cm}, 3,0 \mathrm{~cm}$ dan aspek volume fraction 1\%, $2 \%$ dan $3 \%$ dari volume benda uji silinder. Umur pengujian benda uji untuk kuat tarik adalah 3 hari dan 28 hari dan untuk kuat tekan 3 hari, 7 hari dan 28 hari. Hasil penelitian menunjukkan bahwa serat alami memiliki nilai kuat tarik langsung tertinggi pada panjang serat $2,0 \mathrm{~cm}$ dan aspek volume fraction $3 \%$ sedangkan pada serat fabrikasi nilai kuat tarik tertinggi pada panjang serat 2,0 cm dan aspek volume fraction $2 \%$. Untuk hasil pengujian kuat tekan dan kuat tarik langsung dari Polymer Modified Mortar serat Agave Cantula Roxb tidak berbeda jauh dengan kuat tekan dan kuat tarik dari Polymer Modified Mortar berserat kaca.
\end{abstract}

Kata kunci : serat Agave Cantula Roxb, beton serat, serat kaca, panjang serat, volume fraction.

\section{PENDAHULUAN}

Sifat yang sangat umum pada beton adalah beton kuat terhadap tekan akan tetapi lemah terhadap tarik. Salah satu cara untuk meningkatkan kekuatan tarik pada beton adalah dengan menambahkan serat. Serat yang ditambahkan ada dua macam yaitu serat alami dan serat fabrikasi. Pada peneitian ini jenis serat alami yang digunakan adalah serat Agave Cantula Roxb dan jenis serat fabrikasi yang digunakan adalah serat kaca. Kelebihan dari penambahan serat kedalam matriks yang berupa Polimer Modified Mortar adalah dapat meningkatkan kuat tarik, dan daktilitas pada matriks yang berupa Polimer Modified Mortar. Polymer Modified Mortar adalah mortar dengan kualitas mutu tertentu dengan komposisi bahan tambah campuran yang berupa polymer, accelerator, superplasticizer.

Penambahan serat pada Polymer Moidified Mortar dapat meningkatkan kinerja dari mortar tersebut dikarenakan apabila serat tersebut sudah tercampur dengan mortar maka serat tersebut akan berperan sebagai angkur yang akan menahan retakan pada mortar tersebut sehingga dapat meningkatkan kuat tarik. 


\section{LANDASAN TEORI}

\section{Kuat Tekan}

Menurut SNI 03-1974-2002 kuat tekan beban beton adalah besarnya beban per satuan luas, yang dapat menyebabkan benda uji yang berupa beton hancur. Besarnya nilai kuat tekan dituangkan dalam persamaan berikut ini :

$$
\mathrm{f}^{\prime} \mathrm{c}=\frac{P_{\text {maks }}}{A}
$$

dimana :

f'c = Kuat tekan mortar $(\mathrm{MPa})$

$\mathrm{P}_{\text {maks }} \quad=$ Beban tekan maksimum $(\mathrm{N})$

A $\quad=$ Luas permukaan benda uji $\left(\mathrm{mm}^{2}\right)$

\section{Kuat Tarik Langsung}

Berdasarkan ASTM C-307-03, pengujian kuat tarik langsung dilakukan dengan menggunakan benda uji yang berbentuk dog bone. Nilai kuat tarik langsung didapatkan dari nilai maksimum yang dihasilkan mesin yang dibagi dengan luas penampang benda uji, yang persamaannya sebagai berikut :

$$
f_{c t}=\frac{P_{\operatorname{maks}}}{A}
$$

dimana :

$$
\begin{array}{ll}
f_{c t} & =\text { Kuat tarik mortar semen }(\mathrm{MPa}) \\
\mathrm{P} & =\text { Beban tekan }(\mathrm{N}) \\
\mathrm{A} & =\text { Luas Bidang Tekan }\left(\mathrm{mm}^{2}\right)
\end{array}
$$

Selama proses pengujian benda uji akan mengalami deformasi. Deformasi adalah perubahan bentuk benda akibat adanya gaya yang bekerja pada benda tersebut. Dengan penambahan serat tersebut ke dalam mortar selain menambah kekuatan tarik mortar serat juga dapat menambah deformasi pada mortar tersebut.

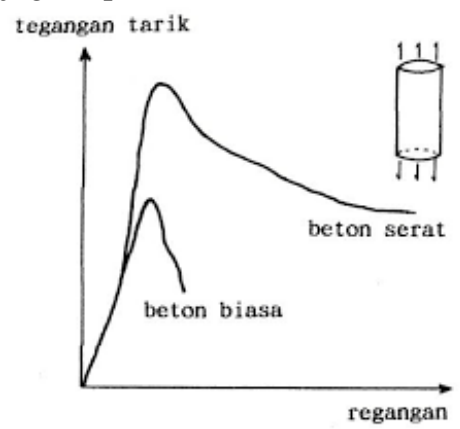

Gambar 1. Perbandingan Uji Tarik Beton Normal dengan Beton Serat.

Adapun di bawah ini contoh mekanisme kerja serat ketika mengalami gaya tarik.

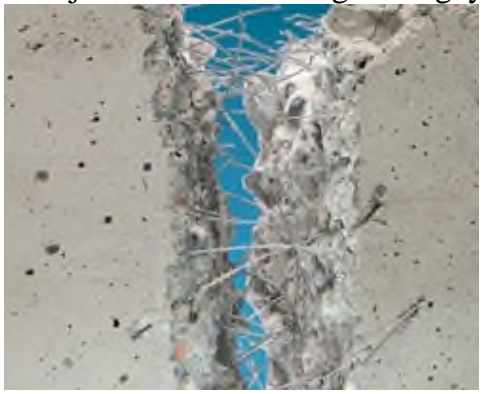

Gambar 2. Mekanisme Kinerja Serat

\section{METODE PENELITIAN}

Metode penelitian dalam penelitian ini adalah eksperimental yang dilakukan di Laboratorium Bahan dan Laboratorium Struktur Teknik Sipil Fakultas Teknik Universitas Sebelas Maret. Benda uji yang digunakan adalah silinder dengan diameter $75 \mathrm{~mm}$ dan tinggi $150 \mathrm{~mm}$ untuk pengujian kuat tekan sedangkan untuk pengujian kuat tarik langsung menggunakan benda uji dengan bentuk seperti dog bone dengan ukuran panjang $150 \mathrm{~mm}$, tebal 10 $\mathrm{mm}$ dan lebar $50 \mathrm{~mm}$.. Setelah mendapatkan hasil pengujian benda uji dan kemudian hasil dari masing - masing benda uji dibandingkan. Dari nilai optimum kuat tarik langsung serat Agave Cantula Roxb di dapatkan aspek rasio panjang optimum untuk digunakan pada langkah selanjutnya yaitu mencari dan membandingkan nilai optimum berdasarkan variasi volume fraction. Tiap variasi terdiri dari 4 buah benda uji tekan dan 4 buah benda uji tarik 
yang akan diuji pada umur 3 hari dan 28 hari. Selanjutnya data hasil pengujian akan diolah menggunakan Microsoft Excel. Model benda uji dapat dilihat pada Gambar 3.
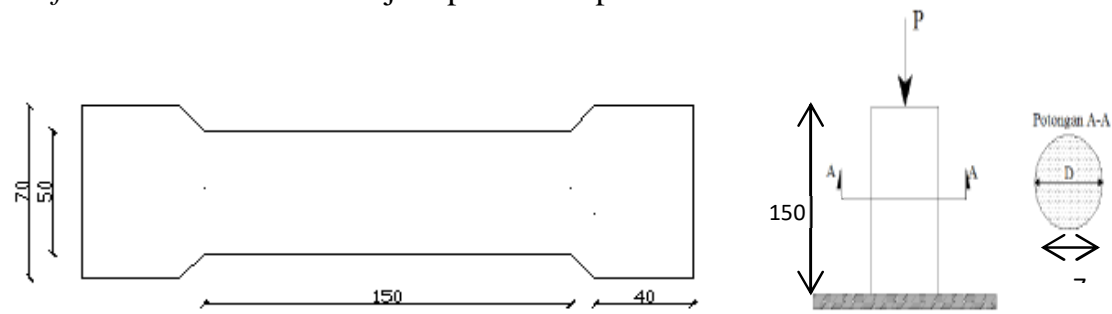

Gambar 3. Model Benda Uji Tarik dan Uji Tekan

\section{HASIL DAN PEMBAHASAN}

\section{Hasil Pengujian Berdasarkan Panjang Serat}

\section{- Pengujian Kuat Tarik Langsung}

Pengujian kuat tarik langsung dilakukan dengan variasi umur 3 hari dan 28 hari. Sebagai contoh diambil data Polymer Modified Mortar berserat Kaca dengan panjang $1 \mathrm{~cm}$, volume serat $2 \%$ dari berat semen, umur 3 hari, dan dengan penampang sebagai berikut :

$\mathrm{P}=447,57 ; \mathrm{t}=9 \mathrm{~mm} ; \mathrm{w}=50 \mathrm{~mm} ; \mathrm{A}=9 \times 50=450 \mathrm{~mm}^{2}$, maka didapat kuat tarik langsung sebesar

$$
f_{c t}=(447,57) / 450=0,994 \mathrm{MPa}
$$

Hasil rekapitulasi akan ditampilkan pada tabel dibawah ini :

Tabel 6. Rekapan Hasil Pengujian Kuat Tarik Langsung Berdasarkan Aspek Rasio Panjang

\begin{tabular}{|c|c|c|c|c|c|c|}
\hline \multirow[t]{2}{*}{ Kode } & \multirow[t]{2}{*}{ Umur (hari) } & \multicolumn{2}{|c|}{$\begin{array}{c}\text { Kuat Tarik Langsung } \\
(\mathrm{MPa})\end{array}$} & \multirow[t]{2}{*}{ Umur (hari) } & \multicolumn{2}{|c|}{$\begin{array}{c}\text { Kuat Tarik Langsung } \\
(\mathrm{MPa})\end{array}$} \\
\hline & & FRCA & FRCF & & FRCA & FRCF \\
\hline $1,0 \mathrm{~cm}$ & 3 & 1,291 & 0,703 & 28 & 1,505 & 1,232 \\
\hline $1,5 \mathrm{~cm}$ & 3 & 1,085 & 0,742 & 28 & 1,091 & 1,260 \\
\hline $2,0 \mathrm{~cm}$ & 3 & 1,574 & 1,452 & 28 & 1,677 & 1,733 \\
\hline $2,5 \mathrm{~cm}$ & 3 & 1,201 & 1,411 & 28 & 1,178 & 1,745 \\
\hline $3,0 \mathrm{~cm}$ & 3 & 1,149 & 1,231 & 28 & 1,363 & 1,701 \\
\hline
\end{tabular}

Dari tabel diatas dapat dibuat grafik yang akan ditampilkan sebagai berikut :

\section{Kuat Tarik Umur 3 Hari Berdasarkan Variasi Panjang}

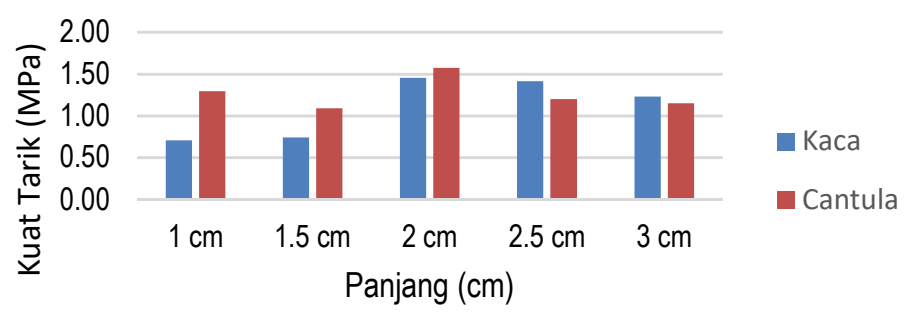

Gambar 5. Grafik Kuat Tarik Langsung Berdasarkan Variasi Panjang Serat

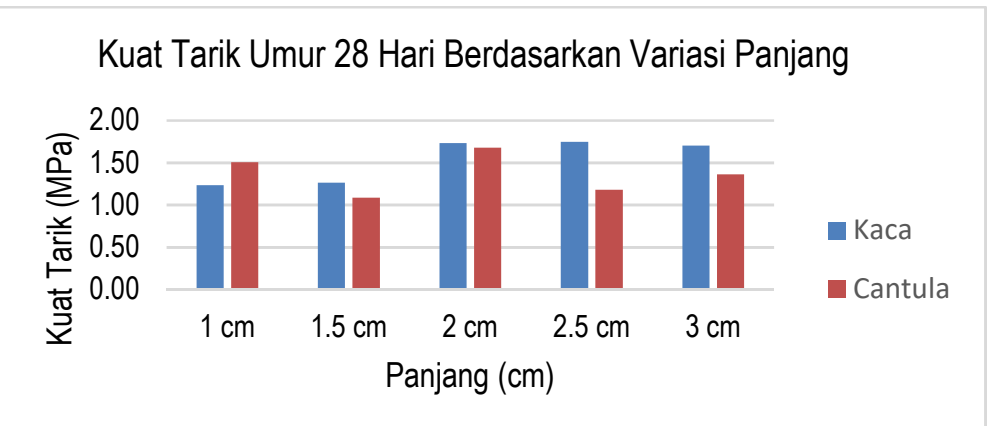

Gambar 6. Grafik Kuat Tarik Langsung Berdasarkan Variasi Panjang Serat 
Berdasarkan grafik di atas dapat diambil kesimpulan bahwa kuat tarik langsung optimum pada umur 3 hari berada pada panjang serat $2 \mathrm{~cm}$ untuk FRCA maupun FRCF. Besarnya kuat tarik langsung untuk FRCA adalah 1,574 Mpa dan untuk FRCF adalah 1,452 Mpa. Pada umur 28 hari nilai kuat tarik langsung terbesar berada pada panjang serat $2 \mathrm{~cm}$ untuk FRCA dan 2,5 cm untuk FRCF, dengan nilai sebesar 1,677 Mpa untuk FRCA dan 1,745 Mpa untuk FRCF. Dapat diketahui bahwa serat Agave Cantula Roxb pada umur 3 hari serat tersebut memiliki kekuatan yang lebih tinggi dari serat kaca namun untuk umur 28 hari kekuatan tarik langsung dari FRCA lebih rendah daripada FRCF.

\section{- Pengujian Kuat Tekan}

Pengujian kuat tekan berdasarkan variasi aspek rasio panjang dilakukan pada umur 3 hari, 7 hari dan 28 hari. Salah satu contoh yang diambil adalah FRCF dengan aspek rasio panjang serat $1 \mathrm{~cm}$ dan volume $2 \%$ dari berat semen yang memiliki penampang dengan $D=75 \mathrm{~mm}, A=1 / 4 \pi \mathrm{D}^{2}=1 / 4 \pi 75^{2}=4415,63 \mathrm{~mm}^{2}$ dan dengan Pmax $=18,74 \mathrm{kN}=18740 \mathrm{~N}$. Maka didapatkan nilai kuat tekan sebesar

$$
\text { f'c }=\frac{18740}{4415,63}=4,24 \mathrm{MPa}
$$

Berikut hasil rekapitulasi pengujian kuat tekan FRCA dan FRCF :

Tabel 7. Hasil Rekapitulasi Kuat Tekan Berdasarkan Variasi Panjang Serat

\begin{tabular}{cccc}
\hline \multirow{2}{*}{ Kode } & Umur (Hari) & \multicolumn{2}{c}{ Kuat Tekan (MPa) } \\
\cline { 2 - 4 } & & FRCA & FRCF \\
\hline \multirow{2}{*}{$1,0 \mathrm{~cm}$} & 3 & 4,097 & 4,047 \\
& 7 & 6,273 & 6,617 \\
\multirow{3}{*}{$1,5 \mathrm{~cm}$} & 28 & 12,599 & 8,882 \\
& 3 & 2,515 & 3,346 \\
\multirow{3}{*}{$2,0 \mathrm{~cm}$} & 28 & 3,836 & 4,571 \\
& 3 & 8,028 & 8,519 \\
\multirow{3}{*}{$2,5 \mathrm{~cm}$} & 7 & 3,652 & 3,266 \\
& 28 & 5,293 & 6,531 \\
\multirow{2}{*}{$3,0 \mathrm{~cm}$} & 3 & 10,793 & 8,431 \\
& 28 & 3,432 & 3,907 \\
& 3 & 4,834 & 6,032 \\
& 7 & 9,821 & 10,810 \\
& 28 & 2,830 & 4,829 \\
& & 8,438 & 6,107 \\
& & 10,745 & 10,903 \\
\hline
\end{tabular}

Dari tabel di atas didapatkan grafik sebagai berikut :

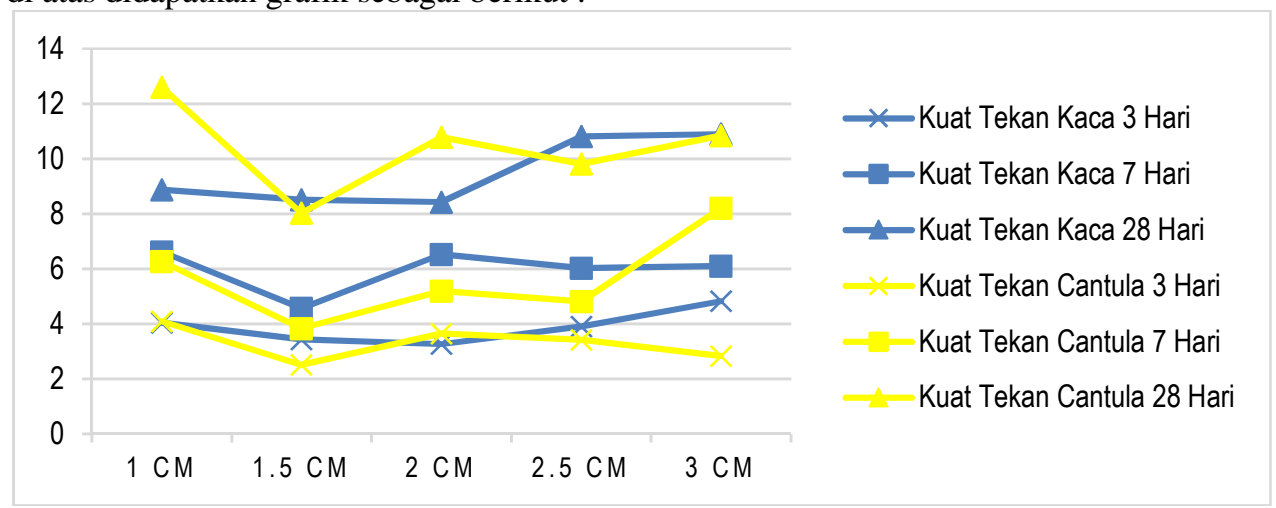

Gambar 7. Grafik Kuat Tekan Berdsarkan Variasi Panjang Serat

Penentuan optimum aspek rasio didasarkan pada kuat tarik langsung maka dapat disimpulkan untuk FRCA mempunyai panjang serat $2 \mathrm{~cm}$ dan untuk FRCF mempunyai panjang serat $2 \mathrm{~cm}$. Berikut adalah grafik perkembangan kuat tekan yang terjadi pada keadaan optimum : 


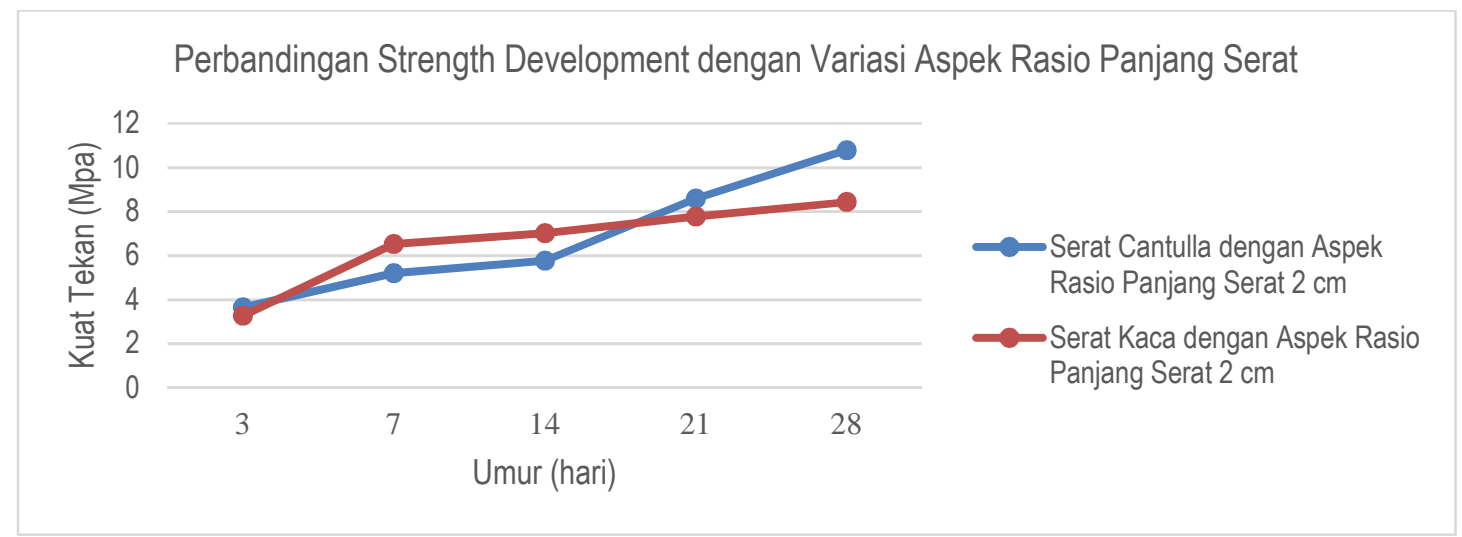

Gambar 8. Grafik Perkembangan Kuat Tekan

\section{Pengujian Berdasarkan Volume Fraction}

\section{- Pengujian Kuat Tarik Langsung}

Berikut adalah hasil rekapitulasi kuat tarik langsung dengan variasi aspek volume fraction dan dengan panjang serat $2 \mathrm{~cm}$ :

Tabel 8. Hasil Rekapitulasi Pengujian Kuat Tarik Langsung Berdasarkan Volume Fraction

\begin{tabular}{cccc}
\hline \multirow{2}{*}{ Kode } & \multirow{2}{*}{ Umur (Hari) } & \multicolumn{2}{c}{ Kuat Tarik Langsung (MPa) } \\
FRCA & FRCF \\
\hline \multirow{2}{*}{$1 \%$} & 3 & 0,755 & 1,476 \\
& 28 & 1,766 & 1,529 \\
$2 \%$ & 3 & 0,796 & 1,734 \\
& 28 & 1,435 & 1,824 \\
\multirow{2}{*}{$3 \%$} & 3 & 0,838 & 0,836 \\
\end{tabular}

Dari tabel hasil rekapan pengujian diatas didapatkan grafik sebagai berikut :

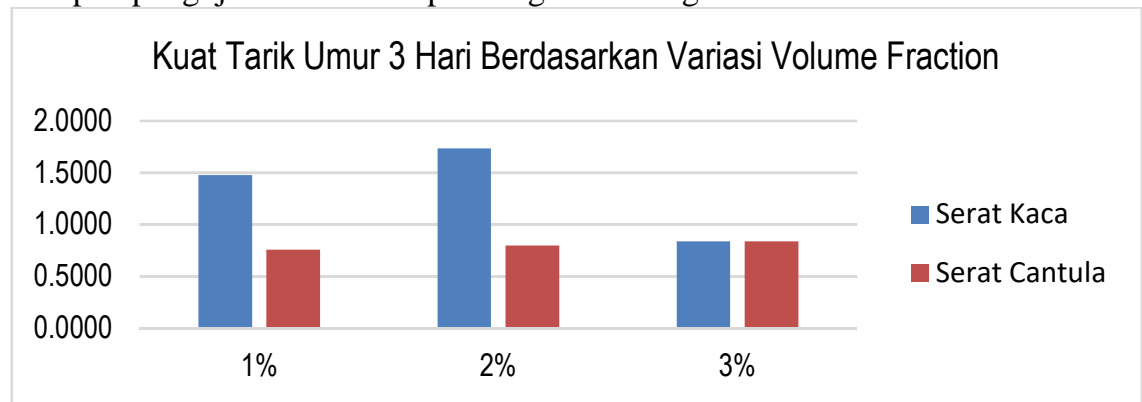

Gambar 9. Grafik Kuat Tarik Langsung Berdasarkan Variasi Volume Fraction

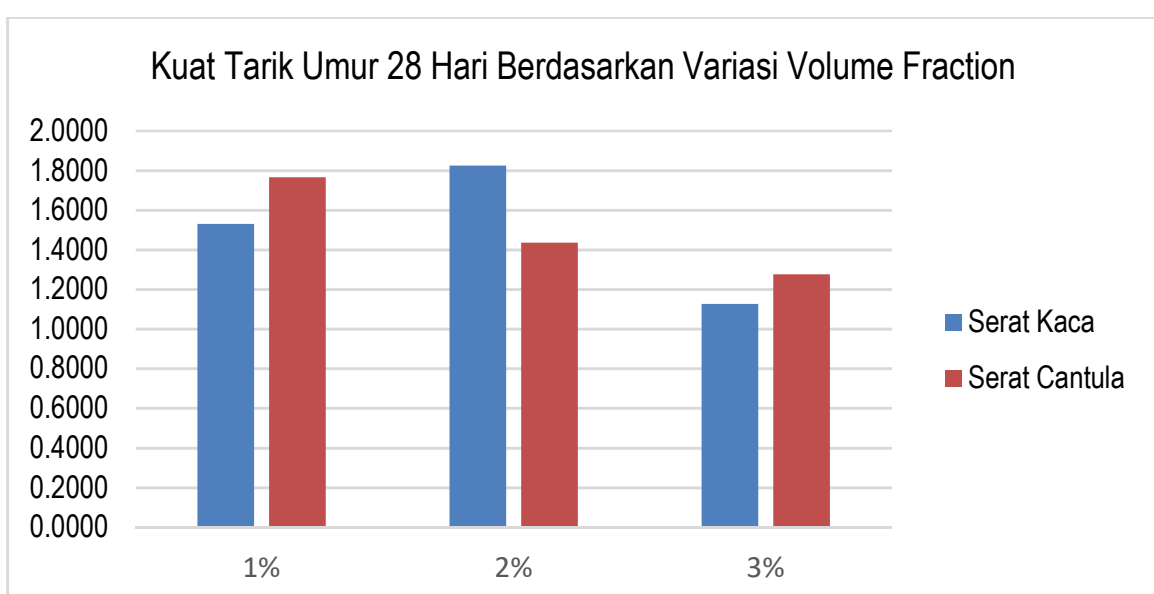

Gambar 10. Grafik Kuat Tarik Langsung Berdasarkan Variasi Volume Fraction 
Pada umur 3 hari perbedaan kuat tarik langsung FRCA dan FRCF terjadi cukup besar pada variasi volume fraction $1 \%$ dan 2\%. Pada volume fraction 3\% nilai kuat tarik langsung antara FRCA dan FRCF mendekati sama, hal tersebut dikarenakan pada volume fraction 3\% FRCF sudah tidak dapat lagi mengalir dan tidak menjadi homogen dengan sempurna. Sedangkan untuk umur 28 hari perbedaan kuat tarik langsung FRCA dan FRCF tidak terlalu besar pada semua variasi volume fraction. Namun hanya pada volume fraction $2 \%$ nilai kuat tarik langsung FRCF lebih tinggi dari nilai kuat tekan langsung FRCA.

\section{Kuat Tekan}

Berikut adalah hasil rekapitulasi kuat tekan berdasarkan variasi volume fraction :

Tabel 9. Tabel Kuat Tekan Berdasarkan Variasi Volume Fraction

\begin{tabular}{|c|c|c|c|}
\hline \multirow{2}{*}{ Kode } & \multirow{2}{*}{ Umur (Hari) } & \multicolumn{2}{|c|}{ Kuat Tekan (MPa) } \\
\hline & & FRCA & FRCF \\
\hline \multirow{3}{*}{$1 \%$} & 3 & 2,981 & 3,172 \\
\hline & 7 & 3,560 & 5,367 \\
\hline & 28 & 8,796 & 7,394 \\
\hline \multirow{4}{*}{$2 \%$} & 3 & 2,092 & 2,594 \\
\hline & 7 & 4,436 & 5,731 \\
\hline & 28 & 6,206 & 8,563 \\
\hline & 3 & 2,038 & 3,523 \\
\hline \multirow[t]{2}{*}{$3 \%$} & 7 & 3,560 & 6,305 \\
\hline & 28 & 10,125 & 7,851 \\
\hline
\end{tabular}

Dari tabel di atas didapatkan grafik sebagai berikut :

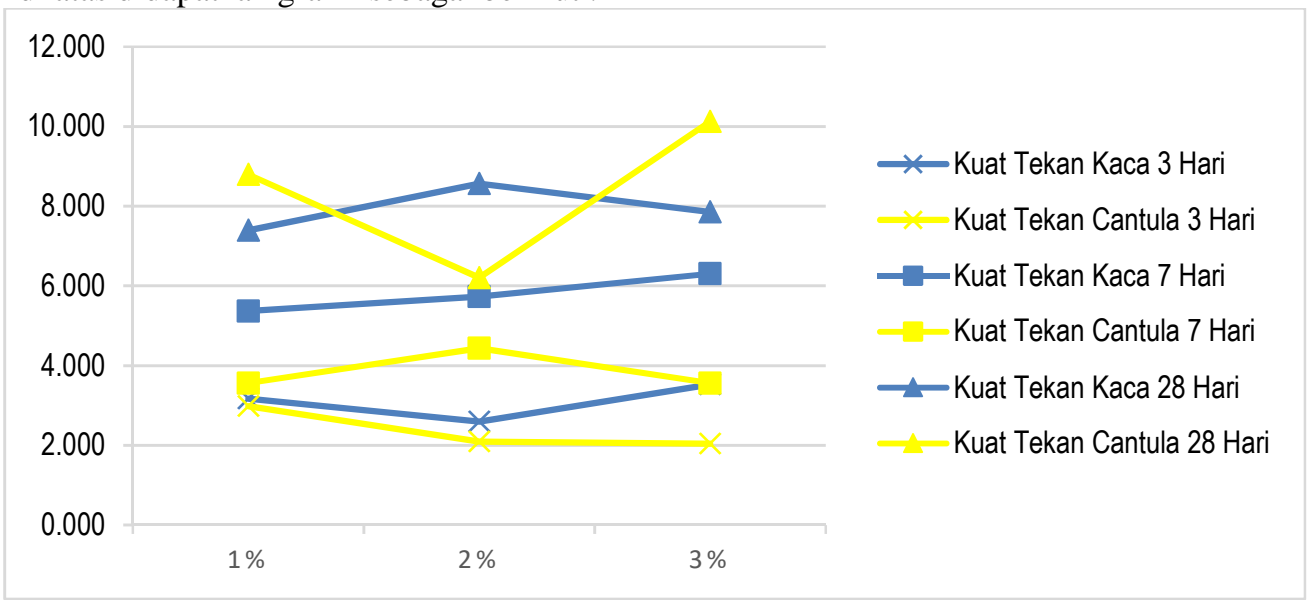

Gambar 11. Gambar Grafik Kuat Tekan Berdasarkan Variasi Volume Fraction

Pada grafik di atas didapatkan kuat tekan terbesar pada umur 3 hari berada pada volume fraction $1 \%$ untuk FRCA sedangkan untuk FRCF berada pada volume fraction 3\%. Untuk umur 28 hari kuat tekan terbesar berada pada $2 \%$ untuk FRCF dan 3\% untuk FRCA. Berdasarkan pada acuan pengambilan nilai optimum diambil dari nilai kuat tarik langsung terbesar. Jadi untuk volume fraction optimum berada pada $3 \%$ untuk FRCA dan $2 \%$ untuk FRCF dengan aspek rasio serat $2 \mathrm{~cm}$. Berikut adalah grafik perkembangan kuat tekan :

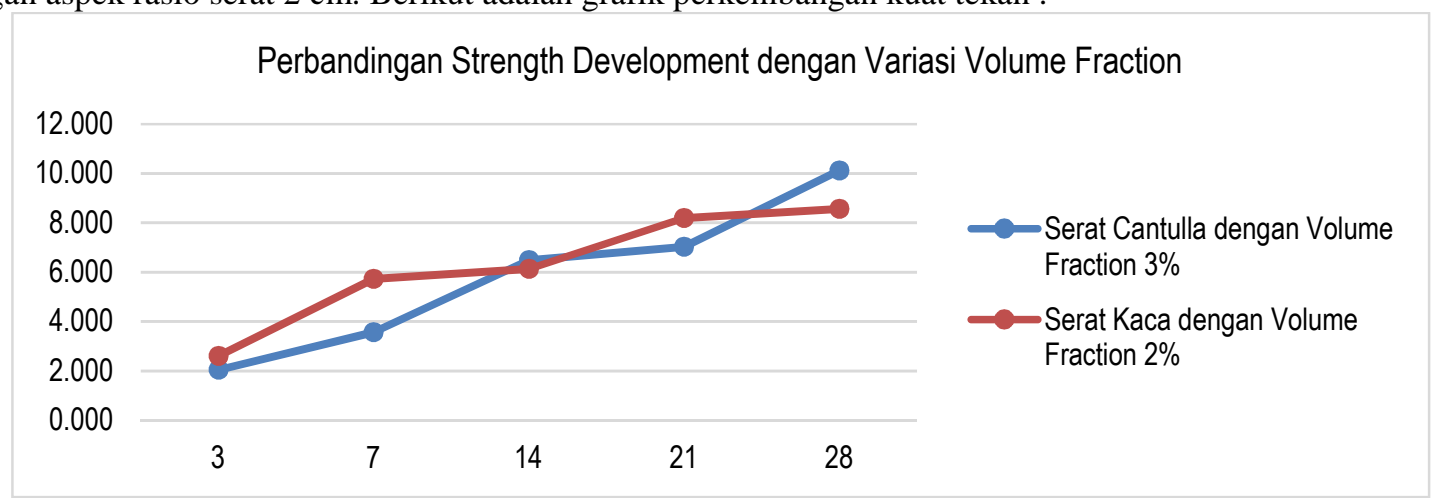

Gambar 12. Grafik Perkembangan Kuat Tekan Berdasarkan Volume Fraction 


\section{SIMPULAN}

Dari hasil pembahasan diatas dapat diambil beberapa simpulan sebagai berikut :

1. Panjang optimum serat yang dicampurkan pada polymer modified mortar (PMM) ditentukan berdasarkan pada kekuatan tarik langsung dari benda uji yang berumur 3 hari. Pada polymer modified mortar berserat Agave Cantulla Roxb (FRCA) panjang optimum berada pada panjang serat $2 \mathrm{~cm}$ dengan nilai kuat tarik langsung sebesar 1,574 Mpa, sedangkan pada polymer modified mortar berserat kaca (FRCF) panjang optimum berada pada panjang serat $2 \mathrm{~cm}$ dengan nilai kuat tarik langsung sebesar 1,452 Mpa.

2. Volume fraction optimum pada FRCA sebesar $3 \%$ dari volume beton, nilai optimum tersebut ditentukan berdasarkan pada kuat tarik langsung terbesar pada umur 3 hari dengan nilai $0,838 \mathrm{Mpa}$. Sedangkan pada FRCF nilai optimum volume fraction adalah $2 \%$, nilai optimum tersebut ditentukan berdasarkan pada nilai kuat tarik langsung terbesar pada umur 3 hari dengan nilai 1,734 Mpa.

3. FRCA memiliki nilai optimum pada panjang $2 \mathrm{~cm}$ dan volume fraction sebesar $3 \%$ dari volume beton, sedangkan pada FRCF berserat kaca memiliki nilai optimum pada aspek rasio panjang $2 \mathrm{~cm}$ dan volume fraction sebesar $2 \%$ dari volume beton.

\section{UCAPAN TERIMA KASIH}

Ucapan terima kasih penulis sampaikan kepada Bapak Edy Purwanto, S.T., M.T. dan Bapak Prof. Stefanus Adi Kristiawan, S.T., M.Sc., Ph.D. selaku pembimbing yang dengan penuh kesabaran telah memberi koreksi dan arahan sehingga menyempurnakan penyusunan.

\section{REFERENSI}

Anonim. 1971. Peraturan Beton Bertulang Indonesia (PBI). Departemen Pekerjaan Umum dan Tenaga Listrik, Bandung.

Anonim. 1982. Persyaratan Umum Bahan Bangunan di Indonesia (PUBI 1982). Bandung : Badan Penelitian dan Pengembangan Departemen Pekerjaan Umum.

ASTM C-128. 2001. Standart Test Methode for Density Relative Density (Spesific Gravity) and Absortion of Fine Aggregate. Annual Books of ASTM Standart USA.

ASTM C-136. 2002. Standart Test Methode for Sieve Analyses of Fine and Course Aggregate. Annual Books of ASTM Standart USA.

ASTM C-494. 2004. Standart Spesification for Chemical Admixture for Concrete. Annual Books of ASTM Standart USA.

ASTM C-1611. 2014. Standart Methode for Slump Flow of Self Compacting Concrete. Annual Books of ASTM Standart USA.

ASTM C-307-03. 2012. Standart Test Methode for Tensile Strength of Chemical Resistance Mortar, Grout and Monolithic Surfacing. Annual Books of ASTM Standart USA.

ASTM C-309-03. 2003. Standart Spesification for Liquid Membrane-Forming Compounds for Curing Concrete. Annual Books of ASTM Standart USA.

ASTM C-109. 2016. Standart Test Methode for Compressive Strength of Hydraulic Cement Mortars (Using 2-in. Or [50-mm] Cube Specimen). Annual Books of ASTM Standart USA.

ASTM C-579-01. 2012. Standart Test Methode for Compressive Strength of Chemical Resistance Mortar, Grout, Monolithic Surfacings and Polymer Concrete. Annual Books of ASTM Standart USA.

ASTM C-150. 2002. Standart Spesification of Portland Cement. Annual Books of ASTM Standart USA.

Dwicahyani, Arum. 2012. Perbandingan Kuat Tekan dan Kuat Lentur Beton Serat Limbah Bubut Besi Terhadap Beton Serat Fabrikasi. Surakarta : Universitas Sebelas Maret Surakarta.

DPU. 1989. SK SNI S-04-1989-F. Spesifikasi Bahan Bangunan Bagian A (Bahan Bangunan Bukan Logam). Bandung : Yayasan LPMB.

Gerung, Lerry. 2012. Pengaruh Serat Daun Nenas dengan Konsentrasi Serat 0,75\% dan Variasi Panjang Serat $0,5 \mathrm{~cm}: 1,0 \mathrm{~cm} ; 1,5 \mathrm{~cm}$ Terhadap Kuat Tarik Beton Normal. Manado :Universitas Sam Ratulangi.

Hafiz, Ahmad dkk. 2015. Pengaruh Pemberian Jumlah dan Rasio (L/D) Serat Bendrat Terhadap Sifat Mekanik Beton. Malang : Universitas Muhammadiyah Malang.

Istanto, Pungky Tri. 2017. Pengaruh Variasi Anyaman Serat Cantula (Agave Cantula Roxb) Terhadap Perilaku Lentur pada Polymer Modified Mortar (PMM). Surakarta : Universitas Sebelas Maret Surakarta.

Mulyono, Tri. 2004. Teknologi Beton. Yogyakarta : ANDI.

Nugraha, Paul dan Antoni. 2007. Teknologi Beton. Yogyakarta : ANDI.

Ohama, Yoshihiko. 1995. Handbook of Polymer-Modified Concrete and Mortars Properties and Pricess Technology. USA : Noyes Publications.

SII 0013-1981. 1981. Mutu dan Cara Uji Semen Portland. 
SNI 15-2049-2004. 2004. Semen Portland. Jakarta : Badan Standarisasi Nasional.

SNI 03-6825-2002.2002. Metode Pengujian Kekuatan Tekan Mortar Semen Portland untuk Pekerjaan Sipil. Bandung : Badan Standarisasi Nasional.

SNI 7974-2013. 2013. Spesidikasi Air Pencampur yang Digunakan dalam Produksi Semen Hidraulis. Jakarta : Badan Standarisasi Nasional.

SNI 03-2847-2002. 2002. Tata Cara Perhitungan Struktur Beton untuk Bangunan Gedung. Bandung : Badan Standarisasi Nasional.

SNI 03-1974-2002. 2002. Metode Pengujian Kuat Tekan Beton. Jakarta : Badan Standarisasi Nasional.

SNI 1972-2008. 2008. Cara Uji Slump Beton. Jakarta : Badan Standarisasi Nasional.

Suhadirman, Mudji. 2011. Kajian Pengaruh Penambahan Serat Bambu Ori Terhadap Kuat Tekan dan Kuat Tarik Beton. Yogyakarta : Universitas Janabadra.

Tjokrodimulyo, K. 2007. Teknologi Beton. Yogyakarta : Biro Penerbit Teknik Sipil Universitas Gajah Mada. 